\title{
Plant growth analysis and seed vigor expression: effects of soil waterlogging during rye plant development ${ }^{1}$
}

\author{
Tiago Pedó2 ${ }^{2}$ Emanuela Garbin Martinazzo ${ }^{3}$, Tiago Zanatta Aumonde ${ }^{4 *}$ and Francisco Amaral Villela ${ }^{4}$
}

Received: April 4, 2014. Accepted: July 1, 2014

\begin{abstract}
This study aimed to evaluate the growth, assimilate partitioning and seed vigor expression of rye seeds subjected to waterlogging during development. The experimental design was completely randomized with six replications and three treatments. The treatments involved different waterlogging periods: a) no waterlogging; $b$ ) single waterlogging of three days; and c) two soil waterlogging periods of three days. The plants were collected at regular intervals of 14 days after emergence until the end of the growth cycle, measuring the dry matter accumulation and the leaf area for growth analysis and dry matter partition between the organs and number of flowers. The other calculated indices included the harvest index and relative seedling emergence rate originating from the seeds of plants that were maintained at field capacity and under the effect of soil waterlogging. Rye plants that were not subjected to waterlogging had a higher dry matter, dry matter production rates and harvest index compared to the plants under the effect of two soil waterlogging periods. Plants under the effect of two waterlogging periods showed drastic alterations in their growth rates and assimilate partitioning during development, and seed vigor expression was negatively affected when the plants were subjected to soil waterlogging.
\end{abstract}

Keywords: germination speed index, net assimilation rates, relative growth rates, Secale cereale L., stress

\section{Introduction}

Rye (Secale cereale) is considered a double-purpose crop, being used as animal feed and as a cover crop, and presents rapid initial growth and winter hardiness as well high tolerance to soil acidity (Roso et al. 2000). In Brazil, Rio Grande do Sul is the state with the largest production of this cereal, which can be a profitable winter crop due to its high dry matter production and excellent crude protein content compared to black oat and triticale (Roso et al. 2000).

In Brazil, there are approximately 33 million hectares of soils that are prone to waterlogging (Ferreira et al. 2008). In the state of Rio Grande do Sul, the approximate extension of lowland soils is 5.4 million hectares (Gazolla Neto et al. 2012), an area managed with relatively low intensity, with the predominance of irrigated rice cultivation and extensive livestock production (Marchezan et al. 2002). The cropping of species that are adapted to temporary waterlogging is an economical alternative to these areas, generating the need for studies of species that could benefit from the infrastructure of rice cultivation (Gazolla Neto et al. 2012). Rye can constitute an alternative to the cultivation these areas, and the evaluation of the physiological traits regulating the growth and assimilate partitioning throughout plant development is an important tool for plant ecophysiology studies (Pedó et al. 2013a).

Waterlogging alters the soil's physicochemical characteristics, impairing gas exchange between the roots and soil pores, thus reducing oxygen availability and negatively affecting processes that are related to the physiology and morphological characteristics of plants (Mielke et al. 2003). Plants under the effect of this abiotic stress exhibit a reduction in protein synthesis and allocation, with a negative impact on the enzymatic activity (Zabalza et al. 2009; Christianson et al. 2010). According to Azevedo Neto et al. (2006), the production and accumulation of reactive oxygen species (chemically reactive molecules containing oxygen) can result in the oxidation of lipids, proteins and nucleic acids. Such alterations can result in the reduction in the root volume, impacting nutrient absorption and leaf senescence, reflecting an inadequate translocation and allocation of assimilates among different plant organs (Pedó et al. 2013a) and reducing the yield and quality of seeds.

\footnotetext{
${ }^{1}$ Integral part of the Doctoral Thesis of the first Author. Financed for CAPES.

${ }^{2}$ Doutorando no Programa de Pós Graduação em Ciência e Tecnologia de Sementes, Bolsista CAPES, Universidade Federal de Pelotas. Departamento de Fitotecnia, Caixa Postal 354 - 96010-900 Pelotas - RS.

${ }^{3}$ Dra. Pós Doutoranda em Fisiologia Vegetal, Bolsista PNPD-CAPES. Universidade Federal de Pelotas, Departamento de Botânica, Caixa Postal 354 96010-900 Pelotas - RS.

${ }^{4}$ Prof. Dr., Universidade Federal de Pelotas, Departamento de Fitotecnia, Programa de Pós-Graduação em C\&T de Sementes. Caixa Postal 354 - $96010-$ 900 Pelotas - RS. *e-mail: tiago.aumonde@gmail.com
} 
Plant growth consists of the production and distribution of carbon among the different plant organs as a result of the interaction between the genotype and environment. Thus, a growth analysis is a fairly inexpensive and accurate method to evaluate plant growth under different management and environmental conditions (Aumonde et al. 2013). This analysis allows for the inference of the contribution by different physiological processes of growth to plant performance and is the first step in the interpretation and analysis of primary production (Pedó et al. 2013b).

The scope of this study was to evaluate the growth, assimilate partitioning and seed vigor of rye plants that were subjected to waterlogging during development.

\section{Material and methods}

This experiment was carried out in greenhouse chapel model, positioned in a north-south orientation, coated with polycarbonate and equipped with temperature and relative air humidity controls, geographically located at coordinates $31^{\circ} 52^{\prime} \mathrm{S}$ and $52^{\circ} 21^{\prime} \mathrm{W}$ at the Federal University of Pelotas (Universidade Federal de Pelotas - UFPel).

Seeds from the rye cultivar BRS Serrano were sown in black polyethylene pots with a capacity of 14 liters that were filled with topsoil on May 25,2012. The substrate soil was obtained from the A1 horizon of a Solodic haplic eutrophic Planosol belonging to the mapping unit of Pelotas (Streck et al. 2008), which was previously corrected for $\mathrm{pH}$ and nutrient concentration according to the previous soil analysis and based on the recommendations of the Fertilization Handbook (Santos et al. 2008). Each polyethylene vase was thinned to four rye plants (Secale cereale L.).

The experimental design was completely randomized with six replications and three treatments. The treatments consisted of different waterlogging periods: a) T1 = absence of waterlogging - the soil was maintained at field capacity; b) $\mathrm{T} 2=$ the soil was subjected to waterlogging during the vegetative phase 51 days after sowing for three days; c) T3 $=$ the soil was subjected to two periods of waterlogging, the first during the active tillering phase 51 days after sowing and the second 81 days after sowing during the booting phase of three days. Flooding was established in such stages of development due to the influence on plant development and the quality of the seeds of different species of the same family (Pedó et al. 2013a).

The polyethylene pots containing topsoil were drilled at the bottom to facilitate the drainage of excess water and to ensure the maintenance of the field capacity state. The field capacity was determined by the voltage table methodology (Sá et al. 2010). Upon defining the field capacity, the volume of water that was required for the establishment of waterlogging for a three-day period was set, maintaining a 20-mm layer of water on the soil surface, which was achieved by fitting a second non-perforated black polyethylene pots under the pots that were filled with topsoil, aiming to avoid gas exchange and soil aeration. To drain the soaked soil, the non-perforated pot was retrieved, allowing the water to drain back to the field capacity level. No non-perforated pots were used in treatment $\mathrm{T} 1$.

The evaluations were performed on the material that was collected at regular intervals of fourteen days after emergence, lasting the entire developmental phase of the rye plants. On each collection date, the plants were clipped close to the ground and manually separated into component organs (roots, leaves, culms and inflorescences), and each fraction was separately placed in brown paper envelopes. To obtain the dry matter content, the material was transferred to a forced ventilation oven at a set temperature of $70 \pm$ $2^{\circ} \mathrm{C}$ for 72 hours.

The seedling emergence test was conducted in a greenhouse using six subsamples of 50 seeds per treatment that were placed to germinate in black polyethylene trays containing the same topsoil as previously described. The trays were maintained at field capacity according to the methodology described elsewhere. The germination speed index was determined through the daily count of the number of emerged seedlings as proposed by Nakagawa (1994).

The leaf area $\left(\mathrm{A}_{\mathrm{f}}\right)$ was determined with a LI-COR model LI-3100 area meter, and the leaf area index (L) was calculated by the formula $L=A_{F} / S_{t}$, with $A_{f}$ for the leaf area and $S_{t}$ for the soil surface that was covered by the plant. The primary data of the total accumulated dry matter $\left(\mathrm{W}_{\mathrm{t}}\right)$ were adjusted by the simple logistic equation: $\mathrm{W}_{\mathrm{t}}=\mathrm{W}_{\mathrm{m}} /\left(1+\mathrm{A} \mathrm{e}^{-\mathrm{Bt}}\right)$, with " $\mathrm{W}_{\mathrm{m}}$ " being the asymptotic estimate of maximum growth, " $\mathrm{A}$ " and "B" adjustment constants, "e" the natural Naperian base logarithm and " $t$ " the time in days after transplantation (Richards 1969). The instantaneous values of the rate of dry matter production $\left(\mathrm{C}_{\mathrm{t}}\right)$ were determined by fitting derived equations for the total dry matter $\left(\mathrm{W}_{\mathrm{t}}\right)$ related to time (Radford 1967). For the instantaneous relative growth rate $\left(\mathrm{R}_{\mathrm{w}}\right)$, the following equation was used: $R_{w}=1 / W_{t} \cdot d_{w} / d_{t}$. The instantaneous values of the net assimilation rate $\left(\mathrm{E}_{\mathrm{a}}\right)$, the leaf area ratio $\left(\mathrm{F}_{\mathrm{a}}\right)$, the leaf mass ratio $\left(\mathrm{F}_{\mathrm{w}}\right)$ and the specific leaf area $\left(\mathrm{S}_{\mathrm{a}}\right)$ were estimated by the equations $\mathrm{E}_{\mathrm{a}}=1 / \mathrm{A}_{\mathrm{f}} \mathrm{d}_{\mathrm{W}} / \mathrm{d}_{\mathrm{t}} ; \mathrm{F}_{\mathrm{a}}=\mathrm{A}_{\mathrm{F}} / \mathrm{W}_{\mathrm{t}} ; \mathrm{F}_{\mathrm{w}}=$ $\mathrm{W}_{\mathrm{f}} / \mathrm{W}_{\mathrm{t}}$; and $\mathrm{S}_{\mathrm{a}}=\mathrm{A}_{\mathrm{f}} / \mathrm{W}_{\mathrm{f}}$ according to Radford (1967), respectively. The harvest index $\left(\mathrm{H}_{\mathrm{i}}\right)$ was estimated by $\mathrm{H}_{\mathrm{i}}=\mathrm{W}_{\mathrm{fv}} / \mathrm{W}_{\mathrm{t}}$, $\mathrm{W}_{\mathrm{fv}}$ being the pod dry matter and $\mathrm{W}_{\mathrm{t}}$ total plant dry matter. The dry matter partition among the different plant structures (roots, culms, leaves and inflorescences) throughout plant development was determined separately, considering the dry mass that was allocated to each plant structure, followed by its transformation on a percentage basis.

All of the collected data were subjected to a variance analysis, and when the $\mathrm{F}$ values were significant, the treatment means were compared through the Turkey test at a $5 \%$ probability. The growth data were analyzed through a simple logistic equation due to the growth analysis being a non-additive and nonlinear model technique that does not comply with the assumptions of the analysis of variance. Additionally, in logistic analyses, errors are correlated over 
time, making them non-independent (Dias \& Barros 2009; Pedó et al. 2013a). Because growth data are of the quantitative type, their trend was evaluated through growth curves (Radforfd 1967; Barreiro et al. 2006).

\section{Results and discussion}

The total dry matter $\left(\mathrm{W}_{\mathrm{t}}\right)$ followed the same trend in all of the treatments, with a with a high determination coefficient $\left(R^{2} \geq 0.91\right)$. The differences in the dry matter production between rye plants appeared due to different waterlogging periods (Fig. 1A). The initial growth rate was slow until day 42 after emergence (DAE), regardless of the waterlogging period, followed by an enhanced growth phase until $140 \mathrm{DAE}$, when the plants that developed at field capacity reached a $\mathrm{W}_{\mathrm{t}}$ of $687.69 \mathrm{~g} \mathrm{~m}^{-2}$. The rye plants that were grown under a single waterlogging period reached a $\mathrm{W}_{\mathrm{t}}$ of $646.83 \mathrm{~g} \mathrm{~m}^{-2}$, while for those under two waterlogging periods, the $\mathrm{W}_{\mathrm{t}}$ was $545.92 \mathrm{~g} \mathrm{~m}^{-2}$.

According to Aumonde et al. (2011), plant growth as a whole, in terms of volume increment, dry matter mass, linear dimensions and structural units, is a function of the structural carbon storage. Slow initial growth is common and can be related to low water and nutrient absorption,
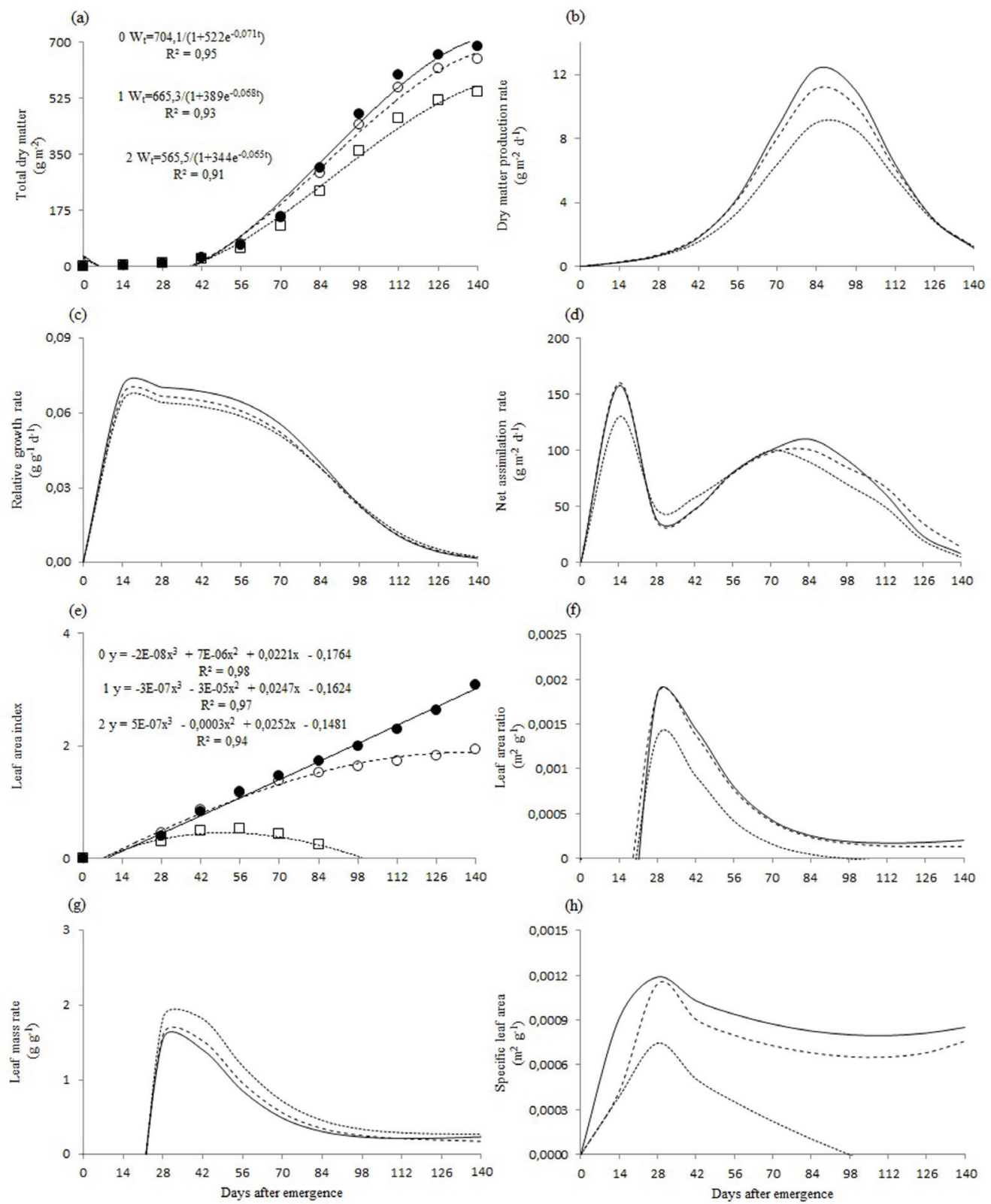

Figure 1. Total dry matter (a), dry matter production rate (b), relative growth (c), net assimilation (d), leaf area index (e), leaf area ratio (f), leaf mass (g) and specific

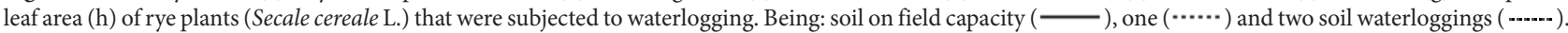


low leaf area and low respiration and net assimilation rates (Chen et al. 2002), attributes that considerably increase throughout the development phase of plants, resulting in enhanced plant growth.

The dry matter production rates $\left(C_{t}\right)$ were initially low and explained the reduced initial growth, as shown by $\mathrm{W}_{\mathrm{f}}$ (Fig. 1A-B). Regardless of the waterlogging period, from 42 DAE onward a phase of high dry matter production ensued, peaking at $84 \mathrm{DAE}$ when the plants that were grown at field capacity showed the highest performance for $C_{t}(12.36 \mathrm{~g}$ $\left.\mathrm{m}^{-2} \mathrm{~d}^{-1}\right)$ compared to those under one $\left(11.13 \mathrm{~g} \mathrm{~m}^{-2} \mathrm{~d}^{-1}\right)$ and two soil waterloggings $\left(8.99 \mathrm{~g} \mathrm{~m}^{-2} \mathrm{~d}^{-1}\right)$, with no differences between them. This result demonstrates that soil waterlogging, regardless of the developmental phase during which it may occur, is not a transient stress without consequences, but that it quantitatively affects the dry matter production rates of rye plants.

Pedó et al. (2013a) suggested that the increase in the dry matter production can, to a certain point, be due to the increase in the leaf area and the amount of synthesized assimilates that were assigned to plant growth and development.

The relative growth rate $\left(\mathrm{R}_{\mathrm{w}}\right)$ demonstrated that all the plants, regardless of treatment differences, reached the highest increments of dry matter at $14 \mathrm{DAE}$, showing a systematic reduction after this point until the final stages of the rye cycle (Fig. 1C). The plants that were maintained at field capacity showed higher values of $\mathrm{R}_{\mathrm{w}}\left(0.070 \mathrm{~g} \mathrm{~g}^{-1} \mathrm{~d}^{-1}\right)$ compared to those under one $\left(0.066 \mathrm{~g} \mathrm{~g}^{-1} \mathrm{~d}^{-1}\right)$ or two $(0.064$ $\left.\mathrm{g} \mathrm{g}^{-1} \mathrm{~d}^{-1}\right)$ soil waterlogging periods, without differences between them.

The relative growth rate tends to be higher at the beginning of plant development due to the leaf area being composed of young leaves with a high photosynthetic capacity and high growth rate. However, the decrease in $\mathrm{R}_{\mathrm{w}}$ with the increase in plant age can be related to the gradual increase in the non-photosynthetic tissues, leading to higher respiration rates, climate oscillations and self-shading, according to what was observed through the leaf area index (Fig. 1DE). The decrease in $R_{w}$ according to Fontes et al. (2005), is related to the decrease in $\mathrm{E}_{\mathrm{a}}$ and $\mathrm{F}_{\mathrm{a}}$.

The net assimilation rate $\left(\mathrm{E}_{\mathrm{a}}\right)$ in rye showed two peaks along the plant ontogeny (Fig. 1D). The $\mathrm{E}_{\mathrm{a}}$ peaked at $14 \mathrm{DAE}$ for the plants that were maintained at field capacity as well as for those that were subjected to a single soil waterlogging, reaching net assimilation rates of 157.82 and $160.28 \mathrm{~g} \mathrm{~m}^{-2} \mathrm{~d}^{-1}$, respectively. The plants that were under the effect of two soil waterloggings averaged lower values with $\mathrm{E}_{\mathrm{a}}=130 \mathrm{~g} \mathrm{~m}^{-2} \mathrm{~d}^{-1}$. A second $\mathrm{E}_{\mathrm{a}}$ peak was established at $98 \mathrm{DAE}$ when the plants that were grown at field capacity reached higher $\mathrm{E}_{\mathrm{a}}$ values compared to those that were under a single waterlogging. Plants from the treatment with two waterlogging periods showed a lower $\mathrm{E}_{\mathrm{a}}$ peak at $70 \mathrm{DAE}$ compared to that of the other treatments.

It is possible to assert that not only the plants that were under field capacity but also those that were exposed to soil waterlogging showed $\mathrm{E}_{\mathrm{a}}$ curves according to the ontogenic pattern. Moreover, a quantitative alteration of $\mathrm{E}_{\mathrm{a}}$ is noticed when submitting the plants to soil waterlogging and modifying temporal-quantitative when exposing the rye plants to two soil waterloggings, indicating that in plants with a higher $\mathrm{E}_{\mathrm{a}}$ with no exposure to soil waterlogging, the difference between photosynthesis and respiration was greater compared to that in the plants that were under abiotic stress (Alaoui-Sossé et al. 2005). Most of the $\mathrm{E}_{\mathrm{a}}$ is due to the increase in the leaf area (Fig. 1E) and, according to the peak that was observed in $\mathrm{E}_{\mathrm{a}}$, can be explained by the increase in the photosynthetic rate of the leaves, seeking to increase the biosynthesis of the carbon compounds and the allocation of the assimilates in the seeds.

Nevertheless, it is important to note that the net assimilation rate is not determined only by the photosynthetic rate but that it is also related to the dimension of the leaf area, the duration of the vegetative period, the distribution of the canopy and leaf angle, the translocation and the carbon partition (Pedó et al.2013a), with an expectation of a higher peak of $\mathrm{E}_{\mathrm{a}}$ at the beginning of plant development (Gondim et al. 2008).

The leaf area index (L) was obtained with a high determination coefficient both in the plants that were under field capacity and those that were under the effect of soil waterlogging $\left(R^{2} \geq 0.94\right)$. Until $14 \mathrm{DAE}$, the leaf area index was low and reduced the $\mathrm{E}_{\mathrm{a}}$ and the $\mathrm{W}_{\mathrm{t}}$ during the mentioned period, with differences between the leaf area index, which increased among the plants that were maintained at field capacity and those that were under the effect of soil waterlogging throughout plant development. It is important to highlight that the plants that were exposed to two soil waterloggings and those that were kept in field capacity, favored by the drastic process of senescence and leaf death, exhibited minor plant growth performance (Fig. 1A, D).

The leaf area ratio $\left(\mathrm{F}_{\mathrm{a}}\right)$ was maximal in the beginning of the development both in the plants that were under field capacity and on those that were under soil waterlogging conditions (Fig. 1F). The maximum values of $\mathrm{F}_{\mathrm{a}}$ were achieved on 28 DAE with a subsequent systematic decrease until the end of the plant development cycle, as the plants that were maintained at field capacity and the plants that were exposed to soil waterlogging showed maximum similarity on the $\mathrm{F}_{\mathrm{a}}$, however, the rye plants that were under the effect of two soil waterloggings exhibited a superior performance.

The higher values of $\mathrm{F}_{\mathrm{a}}$ at the beginning of vegetal development are related to the fact that most of the assimilates from the photosynthetic process are destined to leaf formation for greater solar radiation uptake (Aumonde et al. 2011). However, the decrease that was observed in the curves of $F_{a}$ can be explained by the gradual increase in non-assimilated tissues as well as the formation of the reproductive structures, with a strong definitive drain (Pedó et al. 2013b; Aumonde et al. 2011). The minor $\mathrm{F}_{\mathrm{a}}$ indicates the reduction in the available leaf area during the photosynthetic 
process, as demonstrated in a more evident way for the low $\mathrm{W}_{\mathrm{t}}$ and $\mathrm{C}_{\mathrm{t}}$ that were obtained by the plants that were under the effect of soil waterlogging (Fig.1A-B).

The leaf area ratio $\left(\mathrm{F}_{\mathrm{w}}\right)$ was indifferent to the treatment and was superior and maximum at $28 \mathrm{DAE}$, being superior in the plants that were under a single waterlogging in comparison to the remaining plants (Fig. 1G). Regardless of the treatment used, there was a decrease in the $\mathrm{F}_{\mathrm{w}}$ throughout development; meanwhile, the plants that were under the effect of two soil waterloggings always remained superior to the plants that were under one soil waterlogging or kept under field capacity, which were similar.

The superior $\mathrm{F}_{\mathrm{w}}$ indicates major carbon allocation to the leaves, which, at the beginning of vegetal development, are presented as a strong drain with a high mobilizing capacity of the assimilates (Aumonde et al. 2011). However, the reduction in $\mathrm{F}_{\mathrm{w}}$ can be explained by the fact that throughout the vegetal cycle and with the reproductive structure and culms formation, the leaves lose preference in assimilate investment and begin to export the allocated compounds to organs destined to the perpetuation of the species (Pedó et al. 2013a).

The specific leaf area $\left(\mathrm{S}_{\mathrm{a}}\right)$ was maximum at $28 \mathrm{DAE}$ and superior in the plants that were maintained under field capacity and under the effect of only one soil waterlogging compared to the other plants (Fig. $1 \mathrm{H}$ ), indicating that the plants that are exposed to larger periods of soil waterlogging present smaller leaves that are, however, thicker compared to those of plants that were maintained under field capacity or under the effect of shorter periods of soil waterlogging. It is important to highlight that both $\mathrm{S}_{\mathrm{a}}$ as $\mathrm{F}_{\mathrm{a}}$ presented a negative tendency from $98 \mathrm{DAE}$ on, reflecting the high frequency of senescence and leaf death, as evidenced by the drastic reduction in the leaf area index of the referred period of rye plant development (Pedó et al. 2013a).

The dry matter partition between the different structures of rye plants was altered quantitatively in the plants that were under soil waterlogging effect compared to that of the plants that were maintained under field capacity (Fig. 2).

The plants that were maintained under field capacity presented an assimilate distribution throughout development, with leaves as the structures that are responsible for the better allocation of assimilates until $84 \mathrm{DAE}$, followed by culms and roots (Fig. 2A). With the emergence of spikes at $84 \mathrm{DAE}$, there was a modification of the preferential metabolic drain in which these units containing seeds began to act as a strong (Aumonde et al. 2013).

The plants that were subjected to one and two soil waterloggings, although initially presented a better carbon allocation on the leaves, also presented a larger contribution to the roots of the total dry matter composition (Fig. $2 \mathrm{~B}-\mathrm{C})$. The larger dry matter accumulation in the roots can be due to the new root production, as new roots can retake the lost original radicular system function (Jackson \& Drew 1984). However, the plants that were under the action of a single period of soil waterlogging reached the highest accumulation of dry matter at $118 \mathrm{DAE}$ and remained superior compared to those that were exposed to two periods of soil

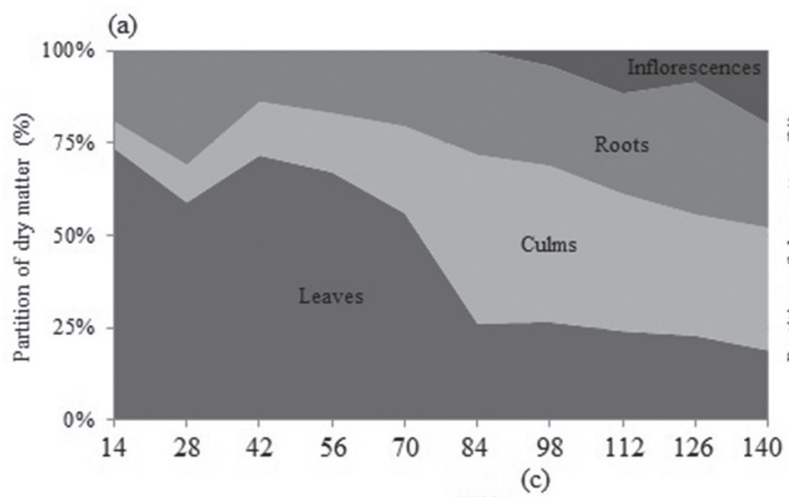

(b)

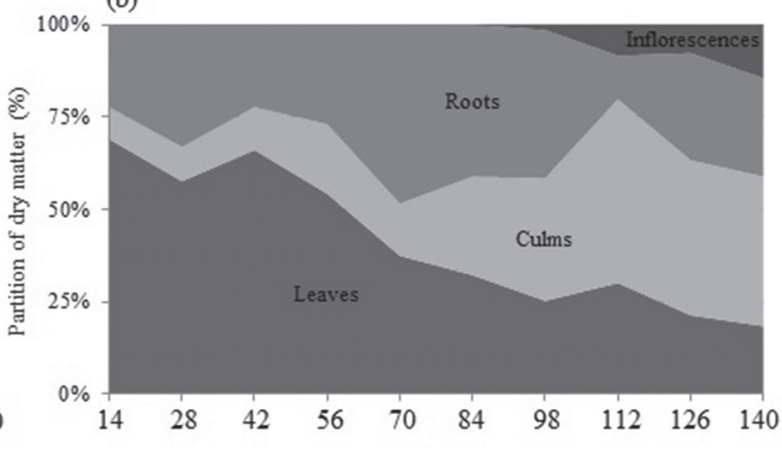

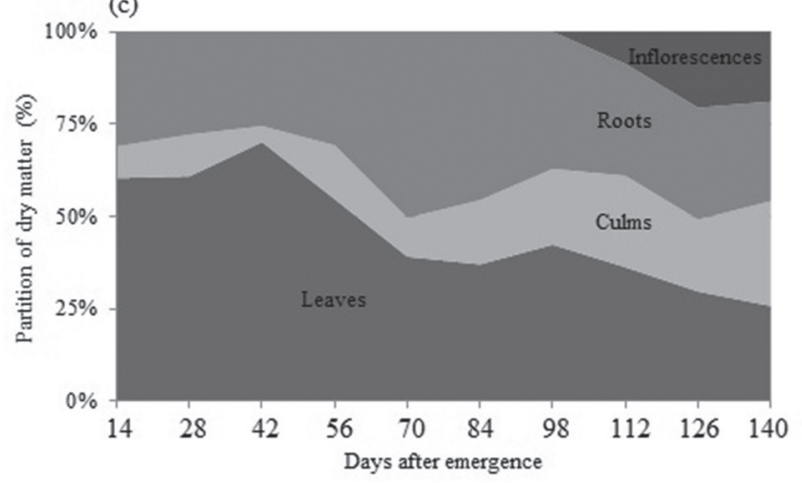

Figure 2. Partitioning of dry matter among different structures of rye plants (Secale cereale L.) that were maintained under field capacity soil (without - a) and in waterlogged soil (one waterlogging $-\mathbf{b}$; and, two waterloggings $-\mathbf{c}$ ). 
waterlogging. This factor may have contributed to a lower direction and allocation of dry matter to the plant culms when subjected to a single period of waterlogging in relation to those under the action of two periods of soil waterlogging.

The harvest index $\left(\mathrm{H}_{\mathrm{i}}\right)$ and the seedling emergence $(\mathrm{E})$ were superior in the plants that were maintained under field capacity or subjected to one soil waterlogging compared to the plants that were subjected to two waterloggings (Tab. 1). However, the emergence speed index (ESI) was superior in the plants with matrices that were kept under field capacity compared to that of the plants that were under the effect of periods of soil waterlogging.

The harvest index reduction indicates that the plants that were subjected to abiotic soil waterlogging stress presented a lower carbon allocation to the seeds, related to the total allocated dry matter of the plant, affecting the physiological potential of seed reduction. The lowest dry matter allocation is related to the efficiency reduction in different physiological and biochemical processes as occasioned by the decrease or absence of oxygen in the soil, which affects respiration and fermentation, resulting in a minor quantity of energy that is available for growth and development (Borella et al. 2013).

However, both the emergence test as the emergence seedling speed index demonstrate a reduction in the vigor expression of the seeds of those plants that originated from the matrices that were maintained under the effect of two periods of soil waterlogging compared to those of the plants that were maintained under field capacity. Therefore, the vigor remains, regarding the proper functioning of the different cell structures that were formed during seed development, the deposition of the appropriate reserves and the effect of the environment, with unfavorable environments affecting the development of the seed and matrices, leading to decreased strength and seed vigor (Peske et al. 2012).

The rye plants that were not subjected to waterlogging had higher $\mathrm{W}_{\mathrm{t}}, \mathrm{C}_{\mathrm{t}}, \mathrm{H}_{\mathrm{i}}$ and ESI compared to those of the plants that were under the effect of two soil waterloggings, which only presented disproportionality in carbon partitioning between the different structures. This way, soil waterlogging for longer periods negatively alters the growth characteristics and partitioning of the assimilates on rye plants, influencing the seed quality.

\section{References}

Alaoui-Sossé B, Gérard B, Toussaint M, Badot P. 2005. Influence of flooding on growth, nitrogen availability in soil, and nitrate reduction of young oak seedlings (Quercus robur L.). Annals of Forest Science 62: 593-600.

Aumonde TZ, Lopes NF, Moraes DM, Peil RMN, Pedó T. 2011. Análise de crescimento do híbrido de mini melancia Smile enxertada e não enxertada. Interciencia 36: 677-681.

Aumonde TZ, Pedó T, Martinazzo EG, Moraes DM, Villela FA, Lopes NF. 2013. Análise de crescimento e partição de assimilados em plantas de maria-pretinha submetidas a níveis de sombreamento. Planta Daninha 31: 99-108.

Azevedo Neto AD, Prisco JT, Eneas Filho J, Abreu CEB, Gomes Filho E. 2006. Effect of salt stress on antioxidative enzymes and lipid peroxidation in leaves and roots of salt-tolerant and salt-sensitive maize genotypes. Environmental and Experimental Botany 56: 87-94.

Barreiro AP, Zucareli A, Ono EO, Rodrigues JD. 2006. Análise de crescimento de plantas de manjericão tratadas com reguladores vegetais. Bragantia 65: 563-567.

Borella J, Durigon MA, Amarante L, Emygdio BM. 2013. Atividade de enzimas fermentativas em raízes e nódulos de soja sob condições de hipóxia e pós-hipóxia. Ciência Rural 43: 970-977.

Chen H, Qualls RG, Miller GC. 2002. Adaptative responses of Lepidium latifolium to soil flooding: biomass allocation, adventitious rooting, aerenchyma formation and ethylene production. Environmental and Experimental Botany 48: 119-128.

Christianson JA, Llewellyn DJ, Dennis ES, Wilson IW. 2010. Global gene expression responses to waterlogging in roots and leaves of cotton (Gossypium hirsutum L.). Plant Cell Physiology 51: 21-37.

Dias LAS, Barros WS. 2009. Biometria Experimental. 1st. edn. Viçosa: Suprema Gráfica e Editora Ltda.

Ferreira JL, Magalhães PC, Borem A. 2008. Avaliação de três características fisiológicas em 4 ciclos de seleção no cultivar de milho BRS-4154 sob o solo encharcado. Ciência e Agrotecnologia 32: 1719-1723.

Fontes PCR, Dias EN, Silva DJH. 2005. Dinâmica do crescimento, distribuição de matéria seca na planta e produção de pimentão em ambiente protegido. Horticultura Brasileira 23: 94-99.

Gazolla Neto A, Aumonde TZ, Pedó T, Olsen D, Villela FA. 2012. Níveis de umidade do solo de várzea e seus efeitos sobre a emergência $\mathrm{e}$ crescimento inicial de plântulas de soja. Informativo Abrates 22: 28-31.

Gondim ARO, Puiatti M, Ventrella MC, Cecon PR. 2008. Plasticidade anatômica da folha de taro cultivado sob diferentes condições de sombreamento. Bragantia 67: 1037-1045.

Jackson MB, Drew MC. 1984. Effects of flooding on growth and metabolism of herbaceous plants. In: Kozlowski TT. (ed.) Flooding and plant growth. Orlando, Academic Press. p. 47-128.

Marchezan E, Vizzotto VR, Rocha MG, Moojen EL, Silva JHS. 2002. Produção animal em várzea sistematizada cultivada com forrageiras de estação fria submetidas a diferentes níveis de adubação. Ciência Rural 32: 303-308.

Mielke MS, Almeida AF, Gomes FP, Aguilar MAG, Mangabeira PAO. 2003. Leaf gas exchange, chlorophyll fluorescence and growth responses of Genipa americana seedlings to soil flooding. Environmental and Experimental Botany 50: 221-231.

Table 1. Harvest index $\left(\mathrm{H}_{\mathrm{i}}\right)$, emergence $(\mathrm{E})$ and emergence speed index (ESI) of rye seedlings (Secale cereale $\mathrm{L}$.) of plants that were maintained under field capacity under the effect of soil waterlogging periods.

\begin{tabular}{cccc}
\hline Treatments & $\mathrm{H}_{\mathrm{i}}$ & $\mathrm{E}(\%)$ & ESI \\
\hline Field capacity & $0.093 \mathrm{a}^{*}$ & $99 \mathrm{a}$ & $9.79 \mathrm{a}$ \\
One waterlogging & $0.081 \mathrm{a}$ & $96 \mathrm{a}$ & $9.26 \mathrm{ab}$ \\
Two waterlogging & $0.031 \mathrm{~b}$ & $88 \mathrm{~b}$ & $8.56 \mathrm{~b}$ \\
CV (\%) & 10.69 & 2.13 & 6.64 \\
\hline
\end{tabular}

${ }^{*}$ Means followed by the same letter on the column do not differ between them the Turkey test, on $5 \%$ possibility. 
Nakagawa J. 1994. Testes de vigor baseados na avaliação de plântulas. In: Vieira RD, Carvalho M. (eds.) Testes de vigor em sementes. Jaboticabal, FUNEP. p. 49-85.

Pedó T, Martinazzo EG, Aumonde TZ, Villela FA. 2013a. Princípios fisiológicos na produção de sementes. In: Schuch LOB, Vieira JFV, Rufino CA, Abreu Júnior J. (eds.) Sementes: Produção, qualidade e inovações tecnológicas. Pelotas, Editora e Gráfica Universitária.

Pedó T, Aumonde TZ, Lopes NF, Villela FA, Mauch CR. 2013b. Análise comparativa de crescimento entre genótipos de pimenta cultivados em casa de vegetação. Bioscience Journal 29: 125-131.

Peske ST, Villela FA, Meneguello GE. 2012. Sementes: Fundamentos Científicos e Tecnológicos. 3rd edn. Pelotas: Editora Universitária UFPel.

Radford PJ. 1967. Growth analysis formulae: their use and abuse. Crop Science 7: 171-175.

Richards FJ. 1969. The quantitative analysis of growth. In: Stewward FC. (ed.) Plant Physiology. A treatise. New York: Academic Press. p. 3-76.
Roso C, Restle J, Soares AB, Andreatta E. 2000. Aveia preta, triticale e centeio em mistura com azevém. 1. Dinâmica, produção e qualidade de forragem. Revista Brasileira de Zootecnia 29: 75-84.

Sá PCC, Vale CNC, Maia CE, Levien SLA. 2010. Índice s e área sob a curva de retenção de água para avaliar qualidade física do solo. Revista Brasileira de Agricultura Irrigada 4: 110-114.

Santos DR, Gatiboni LC, Kaminski J. 2008. Fatores que afetam a disponibilidade do fósforo e o manejo da adubação fosfatada em solos sob sistema plantio direto. Ciência Rural 38: 576-586.

Streck EV, Kämpf N, Dalmolin RSD, et al. 2008. Solos do Rio Grande do Sul. 2nd edn. Porto Alegre: EMATER/RS.

Zabalza A, Van Dongen JT, Froehlich A, et al. 2009. Regulation of respiration and fermentation to control the plant internal oxygen concentration. Plant Physiology 149: 1087-1098. 